\title{
PLIOMAX: Pliocene maximum sea level project
}

\author{
Maureen E. Raymo ${ }^{1}$, P. Hearty ${ }^{2}$, R. De Conto ${ }^{3}$, M. O'Leary ${ }^{4}$, H.J. Dowsett ${ }^{5}$, M.M. Robinson ${ }^{5}$ and J.X. Mitrovica ${ }^{6}$ \\ 'Department of Earth Sciences, Boston University, Massachusetts, USA; raymo@bu.edu \\ ²Bald Head Island Conservancy and Department of Environmental Studies, University of North Carolina, USA; ${ }^{3}$ Department of Geosciences, \\ University of Massachusetts-Amherst, USA; ${ }^{4}$ Department of Environmental and Geographical Sciences, Manchester Metropolitan University, UK; \\ ${ }^{5}$ U.S. Geological Survey, Reston Virginia, USA; ${ }^{\circ}$ Department of Physics, University of Toronto, Canada
}

\section{Accurate estimates of mid-Pliocene sea levels are necessary if we are to better constrain Greenland and Antarctic ice sheet stability in a warmer world.}

The mid-Pliocene climate optimum (3.3$2.9 \mathrm{Ma}$ ) provides both a natural analog and a testing ground for General Circulation Models (GCMs) used for prediction of global warming. However, the value of such model experiments is governed by the quality of available paleoclimate data, and no more important metric of global climate exists than polar ice volume. Estimates of mid-Pliocene sea level range from $+5 \mathrm{~m}$ to $>+40 \mathrm{~m}$ (" + " represents the elevation of sea level relative to present) reflecting a huge range of uncertainty in the sensitivity of polar ice sheets, including the East Antarctic Ice Sheet (EAIS), to a modest global warming. It is the aim of the PLIOMAX project to reduce the level of uncertainty in Pliocene ice-volume estimates by undertaking a field geology program in Australia and engaging, in part through a web-based collaborative, a larger community of geoscientists in surveys of similar high-stand deposits around the world. Determination of the maximum mid-Pliocene sea level rise will allow climate modelers to better assess the level at which atmospheric $\mathrm{CO}_{2}$ concentrations might lead to significant melting of the Greenland Ice Sheet, West Antarctic Ice Sheet (WAIS), and EAIS.

\section{The mid-Pliocene warm period}

The scientific community relies heavily on the predictive capabilities of GCMs (IPCC, 2007) to assess likely future warming scenarios, however, the results of these models can vary greatly between groups, especially in their ability to model different components of the climate system. To address this problem of knowing which models are best, the modeling community puts significant effort into calibrating models against known past climate changes. In particular, many GCM experiments, including the UKMO-GCM (Haywood and Valdes, 2004), the GISS-GCM (Chandler et al., 1994), and the NCAR-Genesis GCM (Sloan et al., 1996) among others, have focused on the mid-Pliocene "climate optimum". This period was the most recent time that Earth's climate was consistently, and for an extended period of time, warmer than the Holocene; with global temperatures elevated by as much as $3^{\circ} \mathrm{C}$ with respect to modern values (Fig. 1; Ravello et al.,

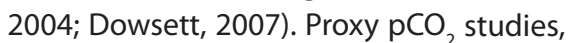
based on techniques that still excite debate, estimate that atmospheric $\mathrm{CO}_{2}$ levels at this time ranged between 350 and 400 ppm, a maximum value that will soon be exceeded. However, the geoscience community has yet to provide an accurate estimate of one critical climate boundary condition and diagnostic of climate sensitivity, namely, the maximum sea level rise, or global ice volume, at this time. Without a firm knowledge of this important parameter, model validation efforts will be doomed to uncertainty.

Why is so little known of the midPliocene sea level, a metric that speaks directly to the stability of the Greenland and Antarctic Ice Sheets (East and West) in the face of a modest warming, and probable $\mathrm{CO}_{2}$ increase, relative to the preindustrial Holocene? Paleoceanographers face difficulties in accurately constraining ice volumes using the deep-sea geochemical records, due to the confounding effects of salinity, temperature, vital effects (i.e., species specific characteristics that can influence isotopic fractionation in foraminiferal shells) and carbonate diagenesis on very small isotopic and trace element signals. More direct field-based estimates of paleo sea level utilize fundamental principles of geomorphology, superposition, and morphostratigraphic succession, combined with absolute geochronological dating of the deposits. The most classic of such studies comes from a raised coastal terrace, the Orangeburg Scarp, located on the coastal margin of southeast USA. After correcting for post-depositional uplift, Dowsett and Cronin (1990) estimate a mid-Pliocene sea level rise of $+35 \pm 18 \mathrm{~m}$. Similar studies of the north and western margin of Alaska resulted in an estimate of $+40 \mathrm{~m}$ (Brigham-Grette and Carter, 1992; Kaufman and Brigham-Grette, 1993). A third classic study of Pliocene sea level, based on coring of a subsiding Pacific atoll, estimated +25 m (Wardlaw and Quinn, 1991). Finally, a few studies of Pliocene sea level have been made based on submarine and subaerially exposed shallow marine deposits. Miller et al. (2005) get a much lower estimate of Pliocene sea level, $+5 \mathrm{~m}$, while

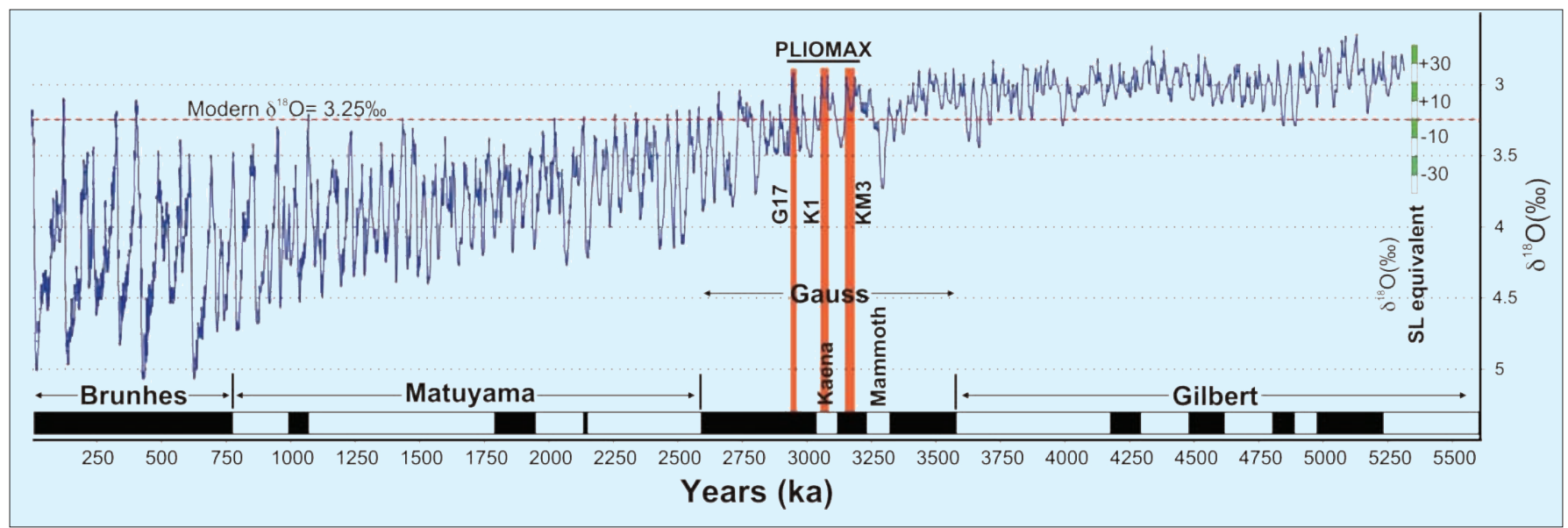

Figure 1: Ice-volume record for the Plio-Pleistocene using the LR04 benthic $\delta^{18} \mathrm{O}$ stack and timescale (Lisiecki and Raymo, 2005). Geomagnetic reversal stratigraphy is shown above the X-axis. PLIOMAX will target three super-interglacial events, G17, K1 and KM3 (orange bars) that are well constrained by magneto- and biostratigraphy. Oxygen isotope inferred sea level changes, assuming no temperature, salinity, diagenetic, or vital effect overprints are shown on the scale on the right. 
Naish and Wilson (2009) estimated sea level oscillations between +10 and $+30 \mathrm{~m}$ during the mid-Pliocene. Although these sea level estimates are highly variable with large uncertainties, most imply partial or complete deglaciation of Greenland and the WAIS and significant drawdown of the EAIS.

\section{Modeling Pliocene ice sheets}

Geologic estimates of maximum Pliocene sea level thus range from +5 to +40 m relative to present, with $+25 \mathrm{~m}$ typically used by the modeling community. In a recent simulation of Antarctic ice spanning the last $5 \mathrm{Ma}$ and using a new ice sheet model with realistic ice shelves and migrating grounding lines (Pollard and DeConto, 2009), the WAIS exhibited highly dynamic behavior, with dramatic retreats during a number of late Pliocene and Pleistocene Antarctic "super-interglacials". The present ice configuration (Fig. 2a) was compared with the smallest Antarctic ice volume obtained in the 5 Ma simulation (Fig. 2b), which is equivalent to $\sim 7 \mathrm{~m}$ of sea level that, if coeval with full Greenland deglaciation, would give a maximum sea level rise of $14 \mathrm{~m}$. In these simulations, most of the ice loss in Antarctica was from the marinebased WAIS and was mainly caused by increased sub-ice ocean melt rather than sea level rise or surface melt. Additional ice loss from Antarctica would require significant surface melt over the flanks of the terrestrial ice sheet, which may be underestimated in the simple parameterized climate used to drive the ice model, especially during the overall warmth of the Pliocene.

GCM and higher resolution regional climate model simulations over the Antarctic region at increasing levels of atmospheric $\mathrm{CO}_{2}$ (400 ppmv) and with warm austral summer orbits, so far fail to produce surface air temperatures capable of producing significant surface melt (R. DeConto, unpublished work in progress). Taken together with the results shown in Figure $2 \mathrm{~b}$, one may conclude that: a) Pliocene $\mathrm{CO}_{2}$ or levels of other greenhouse gases may be underestimated; $b$ ) the sensitivity of the GCM to $\mathrm{CO}_{2}$ is far too low (especially over the poles); $c$ ) the ice sheet model does not adequately represent some of the important underlying physics (e.g., sub-glacial hydrology); d) most sea level estimates for this time period, including the $+25 \mathrm{~m}$ average cited by many investigators, are too high, or e) some combination of the above. Note that an added complexity in paleo sea level reconstructions results from the tectonic displacement of or iceloading deflections of the original shoreline position, which can cause significant departures of observed sea level change from the eustatic (global changes in sea level due to water mass added or removed from the oceans) rise or fall due solely to the ice volume change (e.g., Moucha et al., 2008; Milne and Mitrovica, 2008).

\section{Summary}

A coordinated multidisciplinary approach to the problem of Pliocene sea level is needed; one that combines additional field studies with climate modeling and geophysical modeling of the mantle and crustal response to ice sheet loading. We hope the knowledge gained during our upcoming field expedition to Australia will contribute to narrowing the range of midPliocene sea level estimates and that parallel modeling efforts will guide and inform not only our investigations but also those in other regions of the world. Warming of the current climate system is unequivocal. The most conservative estimates suggest a further $1-2^{\circ} \mathrm{C}$ of global temperature rise can be expected, even if massive reductions in greenhouse gas emissions were to occur. It is because climate is locked into this temperature trajectory, at least in the near-term, that understanding climate and ice sheet dynamics under warmer conditions takes on added urgency. A robust estimate of eustatic sea level change during the mid-Pliocene warm period will provide an important target for the GCM climate modeling community actively engaged in experiments on this time period.

\section{References}

Chandler, M., Rind, D. and Thompson, R., 1994: Joint investigations of the Middle Pliocene climate II: GISS GCM Northern Hemisphere results, Global Planetary Change, 9: 197-219.

Dowsett, H.J., 2007: The PRISM Palaeoclimate Reconstruction and Pliocene Sea-Surface Temperature. In: M. Williams, et al. (Eds) Deep-time perspectives on climate change: marrying the signal from computer models and biological proxies, The Micropalaeontological Society Special Publications, The Geological Society of London.

Haywood, A.M. and Valdes, P.J., 2004: Modelling Middle Pliocene warmth: contribution of atmosphere, oceans and cryosphere, Earth Planetary Science Letters, 218: 363-377.

Lisiecki, L.E. and Raymo, M.E., 2005: A Pliocene-Pleistocene stack of 57 globally distributed benthic ${ }^{18} 0$ records, Paleoceanography, 20 PA1003, doi:10.1029/2004PA001071.

Pollard, D. and DeConto, R.M., 2009: Modeling West Antarctic Ice Sheet growth and collapse through the last 5 million years, Nature, 458: $329-332$

For full references please consult:

www.pages-igbp.org/products/newsletters/ref2009_2.html
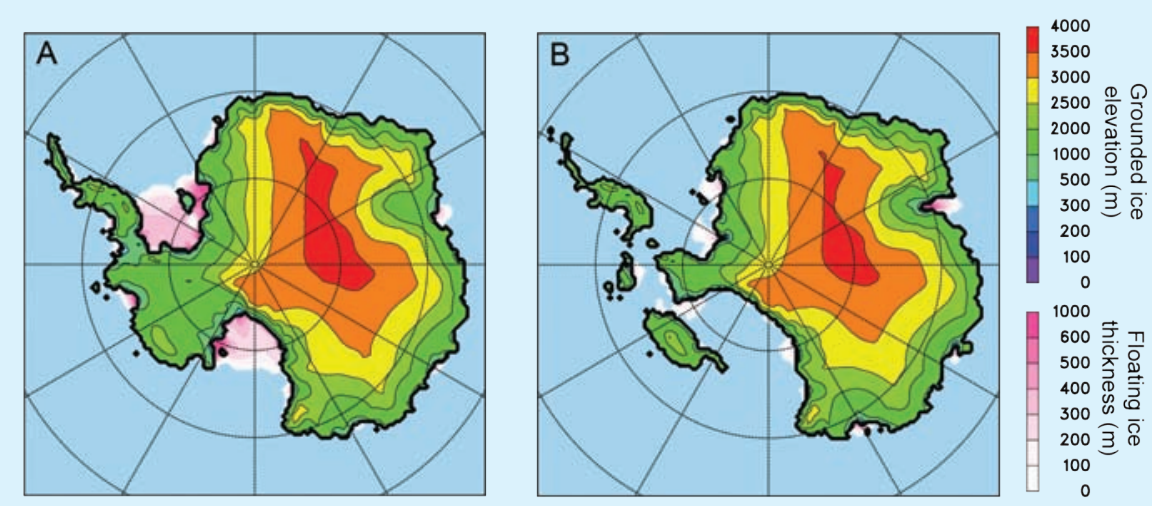

Figure 2: Ice elevations (grounded) and ice thickness (floating) in meters, for present day (A) and during a Pliocene interglacial (B) as simulated by an ice sheet-shelf model (Pollard and DeConto, 2009). The model is driven by a parameterized climatology and oceanic sub-ice melt rates derived from deep-sea core isotope records (Lisiecki and Raymo, 2005) and local insolation. The loss of ice in B is equivalent to $7 \mathrm{~m}$ of sea level rise, far less than that required to account for some Pliocene sea level estimates. 